\title{
Turning Migration Disadvantage into Educational Advantage. Autobiographies of Successful Students with an Immigrant Background
}

\author{
De la desventaja de la inmigración a la ventaja educativa. \\ Autobiografías de estudiantes exitosos de origen inmigrante
}

\author{
Mariagrazia Santagati ${ }^{1}$
}

\begin{abstract}
The article focuses on unexpected pathways of successful students with an immigrant background, in order to investigate the implication of this phenomenon from a theoretical, methodological and empirical point of view. After a review of the main sociological studies on «immigrant optimism» towards educational success, I will reflect on biographical approach, particularly suitable to study this topic. A on-going research project based on the collection of educational autobiographies of successful immigrant-origin students, attending upper secondary schools in Northern Italy, is presented. Then, the story of Destiny, a 16 years-old girl with Moroccan origin, is used as a case study to explore transformative actions that lead second-generation students to educational success and to identify the social logic enrolled in a single case. Destiny, with the support of parents and teachers, shows the capacity to turn the disadvantage of migration into an educational advantage, through specific strategies developed to contrast adversities and inequalities, assuming education to handle social constraints. In Destiny autobiography, migration reveals its nature of biographical resource and its important role to lead disadvantaged students to excellent school outcomes: migration appears as a an experience of familiar sufferance and failure, but also a source of a biographical learning; a chance of reflexivity on failure and of awareness of disadvantage; an experience that transmit and foster non-cognitive skills, that are strong predictor of educational success. The methodological choice of «educational autobiography» is thus considered crucial to track new narratives and discourses on ethnic inequalities in education.
\end{abstract}

Keywords

Immigrant-origin students, immigrant optimism, educational autobiography, migration as a biographical resource.

\section{Resumen}

El artículo se enfoca en las improbables e inesperadas rutas escolares de los alumnos de origen inmigrante, caracterizadas por el rendimiento académico positivo y el éxito del proyecto educativo y biográfico, con el fin de investigar las implicaciones de este fenómeno desde un punto de vista teórico, metodológico y empírico. Después de una revisión de los principales estudios sociológicos sobre el «optimismo inmigrante» hacia el éxito educativo, se reflexiona sobre el enfoque biográfico, particularmente adecuado a ese tema. Además se presenta un proyecto de investigación basado sobre la colección de autobiografías educativas de estudiantes exitosos de origen inmigrante de escuelas secundaria superiores. Luego, la historia de Destiny, una niña de 16 años de origen marroquí, se utiliza como estudio de caso para explorar acciones transformadoras que llevan a los estudiantes de segunda generación al éxito educativo y a identificar la lógica social inscrita en un solo caso. Destiny, con el apoyo de sus padres y maestros, muestra la capacidad de convertir la desventaja de la migración en una ventaja educativa, a través de estrategias específicas desarrolladas para contrastar las adversidades y las desigualdades, asumiendo la educación como para manejar esas limitaciones sociales. En la autobiografía de Destiny, la migración revela su naturaleza de recurso biográfico y su importante papel para el éxito escolar de los desfavorecidos: la migración aparece como una experiencia de sufrimiento familiar y fracaso, pero también una fuente de aprendizaje biográfico; una oportunidad de reflexividad sobre el fracaso y de conciencia de las desventajas; una experiencia que permite desarrollar habilidades no cognitivas, que son un fuerte predictor del éxito educativo. La elección metodológica de la «autobiografía educativa» se considera así crucial para dibujar nuevas narrativas y discursos sobre las desigualdades étnicas en la educación.

\section{Palabras clave}

Estudiantes de origen inmigrante, optimismo inmigrante, autobiografía educativa, migración como recurso biográfico.

1 Department of Sociology, Università Cattolica del Sacro Cuore (Milan), CIRMiB (Centro di Iniziative e Ricerche sulle Migrazioni - Brescia); mariagrazia.santagati@unicatt.it 


\section{Introduction}

In the context of a long-lasting socio-economic crisis which has produced dramatic consequences on the lives of all European citizens, immigrant-origin youngsters suffer from specific vulnerabilities regarding education: lower academic performances compared to natives (OECD, 2016); an higher risk of dropout; difficulties in accessing non-compulsory education (non-vocational secondary education and higher education); a higher likelihood of joining the NEET group (young people not in employment, education or training). Despite researchers and policy-makers have focused mainly on the causes of failure, data show that school success is possible for socio-economically disadvantaged students with an immigrant origin. The presence of these students - for whom educational attainment/achievement determines the likelihood of successful integration in adulthood - questions the traditional explanations of educational inequalities, based on disadvantaged family background and inheritance of social disadvantage from one to another generation of immigrants (Bourdieu and Passeron, 1970).

In fact, the so-called «resilient students» are a common feature in some educational systems (OECD, 2011: 22): they are those who beat the odds and succeed at school despite highly adverse circumstances (such as migration: Masten et al., 2012). In 2015 on average across OECD countries, 24\% of socioeconomically disadvantaged immigrant students are considered resilient - compared to 30.5\% of nonimmigrant students (OECD, 2016). Among high-performing economies with relatively large immigrant student populations (i.e. Australia, Canada, UK, USA), more than one in three of all disadvantaged immigrant students are resilient ${ }^{2}$. How are immigrant students able to turn their social disadvantage deriving from migration into an educational advantage in their pathway towards academic achievement? This seems to be an interesting research question - how actors negotiate structural and cultural opportunities and constraints -, that is quite under-investigated in international studies on ethnic inequalities in education (Stevens and Dworkin, 2014: 628-9).

Consequently, this article focuses on improbable and unexpected pathways of successful students with an immigrant background, in order to investigate the implication of this phenomenon from a theoretical, methodological and empirical point of view. 1. I will provide a review of the main sociological studies dealing with this topic in the US and in Europe, highlighting different explanations of «immigrant optimism» towards educational success of children, linked to the family driver or to role of a facilitating institutional context. 2. I will reflect on the biographical approach that seems to be particularly suitable to give an analytical frame for understanding success stories of immigrant students. Through the biographical lens, it is possible to investigate the process that leads immigrant students to contrast educational inequalities, assuming education to react and handle social, economic and cultural conditionings. 3. I will present an on-going research project, a qualitative study based on the collection of educational autobiographies of successful immigrant-origin students attending upper secondary schools in a Northern province of Italy (Brescia). Aims and methodological choices of the research project are useful to reflect on new ways to shed light on ethnic inequalities in education, on social constraints and individual factors that affect educational pathways in positive direction. 4. I will analyse the autobiography of Destiny, a 16 years-old girl with Moroccan origin, attending a scientific lyceum in Brescia. Her autobiography is used as

\footnotetext{
Resilience among immigrant-origin students varies markedly across countries. According to PISA data, in 2015 in Italy the percentage of resilient students is similar both among immigrant students and natives ones: $23.7 \%$ of disadvantaged immigrant students in Italy are resilient compared to $27 \%$ of native students. On the other side, resilient native students in Spain (42\%) are twice as large as immigrant ones (27.4\%). Cebolla-Boado (2014) highlights that in Spain educational inequalities among immigrant students are not only explained by family background. If compared with families with the same socio-economic conditions and the same access to the educational system, immigrant families seem to be less able to use with efficacy these resources to support their children toward educational success.
} 
a case study to start exploring transformative actions that lead second-generation students to educational success. She is the protagonist of a «positive integration,» despite the structural obstacles placed in their way by the school and social system of the country of arrival: in her autobiography, she is able to turn the disadvantage of migration into an educational advantage in terms of determination, capacity to deal with failure, learning to succeed thanks to her novel approach towards understanding adversity. In conclusion, I will reflect on the nature of migration as a biographical resource, that can lead immigrant students to excellent school outcomes, considering the role played by these successful disadvantaged students, and also by scholars that give them directly a voice through autobiographies, in the production of alternative/ public narratives on ethnic inequalities in education.

\section{Immigrant optismism in America and in Europe}

The perspective of «immigrant optimism» is particularly suited to understand the successful autobiographies of immigrant-origin students. It is a frequent pattern, found in many national contexts.

\subsection{Immigrant families as a driver of educational success}

US scholars introduce the fruitful hyphotesis of «immigrant optimism,» underlining the enormous driver deriving from the positive attitude of parents towards future, necessary to succeed without any proper family resources and with expectations higher than achievements (Kao and Tienda, 1995). Migration is considered a family project of intergenerational mobility and parents' optimism about their offspring's prospects are decisive in the educational outcome of immigrant-origin youth. All immigrant parents, as pointed out by Portes and Hao (2004), regardless of nationality, have high educational aspirations for their children and are willing to make major sacrifices to achieve these goals.

Also in many European countries many researchers refer to the idea of «an immigrant optimism»: children of immigrants spend a relatively long time in education and choose more ambitious educational trajectories (secondary effects of educational inequality) than might be expected either from their school results (primary effects) or from their family's social background, even despite difficulties (UK case: Jackson, 2012). Choice effects have an important role in the trajectories of these second-generation students, to the extent that ethnic disadvantage in performance is mitigated by "ethnic advantage in choice" (Sweden: Jonsson and Rudolphi, 2011). Within this international scenario, it is interesting to analyse if similar trends can be seen in new immigration countries like Italy and Spain, characterized by recent immigration flows, low-productivity economies, dynamic informal sectors, and a high rate of low-skilled and low-qualified immigrant population (Riba-Mateos, 2004). Despite the academic difficulties of immigrant youth, Garreta Bochaca $(1994 ; 2011)$ identifies in Spain a group of immigrant parent that consider education as a platform for social mobility, giving a great importance to the school project of their offspring and with a big investment on education, typical strategy of working-class families (Pérez Sánchez et al., 2014). Moreover, studies on PISA data also reveal that second-generation pupils in Spain perform as well as their native peers do (Álvarez Sotomayor et al., 2015; 2018). The ILSEG, «Investigación Longitudinal de la Segunda Generación» - Spanish version of US-CILS of Portes -, through a sample of 7,000 children of immigrants attending 180 schools in the metropolitan areas of Barcelona and Madrid reaches positive results, highlighting a good process of integration of foreign groups in Spanish society and a convergence between second-generation students and Spanish youngsters. Immigrant and native students show the same level of ambition (real expectation plus ideal aspirations), taking part of the same universe of youth with similar plans (Portes, Aparicio, Haller, 2017). 
Italy, as well as other Mediterranean countries, shows a great influence of social origin on educational pathways (Schnell and Azzolini, 2015): the achievement gap faced by immigrant children is due to fewer economic resources, deriving from the very precarious socio-economic integration of adult immigrants who, despite their relatively strong educational credentials, are placed into the lowest occupational positions (Azzolini and Barone, 2013). However, Italian studies suggest also that «successful migrants» exist, those managing to finish upper secondary education and showing a high interest in higher education (Bertozzi, 2018). They may even have more assets than natives - they know more languages and are more prone to move abroad for work purposes. Young graduates with an immigrant background (Ceravolo, 2016) are featured by specific skills: 1) multilinguism, to be considered an advantage in terms of available human capital and for the predisposition to learn new languages; 2) a «migrant habitus,» defined as an ability to adapt socially and culturally into a new context, to successfully mix elements from native and non-native cultures. In Italy, Eve (2015) directly tests the hypothesis of immigrant optimism, analyzing the educational decision-making process in immigrant families through a qualitative study: children of immigrants in Italy, not dissimilar to elsewhere, are featured by an «aspirations-achievement paradox»; they do have relatively high aspirations, especially considering family background and school results, and show a significant persistence in spending a relatively long time in education, even in spite of difficulties.

\subsection{The contribution of the integration context theory}

In Europe, Maurice Crul has been studied successful second-generation youth in different European countries since Nineties, emphasizing the importance of structural factors in the educational system that prevent or help children of immigrants to succeed ${ }^{3}$. In a recent comparative research project (Crul et al., 2016), the scholar refers to the concept of «new élites,» including young people with parents of lower socio-economic status, who gain entry into high-ranking positions of leadership, a group that face specific challenges, obstacles and barriers when moving up to leadership positions. In this project, Crul and the other researchers continue to develop the «integration context theory» (Crul and Schneider, 2010): this approach points out that differences in institutional arrangements in education (i.e. pre-school facilities, the amount of school contact hours, selection and tracking mechanisms, and alternative pathways to higher education) and in the labour market affect the possibilities for upward social mobility among children of immigrants (Crul, 2013). Crul and colleagues link the idea of the specific drive in immigrant families, prevalent in the American literature, to the theoretical idea of looking at institutional barriers and opportunities in education and the labour market, in order to see how people manage institutional challenges and find ways and alternative routes to succeed. They find new patterns of social mobility: in fact, alternative routes to achieving a successful position exist and second-generations are moving into a social world that their ethnic group has never before inhabited in the country of immigration. This European study shows how it is possible to accumulate social and cultural chances over time, while moving up the social ladder, thus breaking the perpetual cycle of the habitus inherited through class position (Bourdieu, 1990). Initially, small chances open to other possibilities and are the starting point for further gains, with a sort of snowball effect called «the multiplier effect» (Crul et al., 2017).

\footnotetext{
See the ELITES Pathways to Success project, coordinated by Crul and started in 2012, that is the first international and comparative project focused on success trajectories and upward mobility of second-generation immigrants in 8 European cities (and 4 countries: France, Germany, Sweden, and the Netherlands). Cf. https:// www.elitesproject.eu/pathways-to-success.
} 
Italian research has also identified success-oriented types, among whom it is possible to recognize resilient ones, characterized by a positive vision of the future and composed especially of brilliant and ambitious female students that aspire to improve their condition (explorative achiever type), investing in training towards professionalization and personal fulfillment (Colombo and Santagati, 2010). Immigrant students attending secondary schools are represented as a strategic generation and featured by «full integration» (Colombo and Santagati, 2017), able to carry out educational plans that are at the same time bound to and free from family expectations and prearranged destinies. More recently, through a qualitative study on youth conditions carried out in Milan and Naples, Eve (2017) also questions whether immigrant «optimism» is an appropriate term in the Italian case. In general, children of immigrants do seem to be more ambitious than their Italian classmates. However, their ambitions are reduced by being in less academic tracks. Eve points out the existence in Italy of an «unorthodox route» to university, since the Italian school systems offer alternative and often longer pathways to higher education (through technical and vocational education). This is possible, since all high school diplomas give access to university, but it is not the normal or expected way; it is an unorthodox route that requires extra-effort of immigrant students and is not really foreseen by teachers (Bonizzoni et al., 2014).

\section{Education and migration through the lens of the biographical approach}

International studies on educational pathways of children of immigrants generally do not focus on narratives of personal success and on mechanisms that allow to turn disadvantage into an advantage, but theorize integration as a reachable endpoint by putting emphasis on educational and occupational performances and achievements (Konyali, 2014).

In this perspective the biographical approach offers a way of analyzing the transformational character of migration phenomena through biographical narration (Ruokonen-Engler and Siouti, 2014: 249). Furthermore, it is useful to interpret the migration-education-leaning nexus: according to Morrice (2014: 157-158), there is unpredictability around migration and learning, because learning is multi-faceted and can have both positive and negative outcomes for the migrant. For migrants learning is an inevitable part of life (Ibidem: 152) and migration is considered a life event in which learning becomes so wholly part of daily life experience: negative outcomes are linked to the idea that linguistic skills, education, employment qualifications, experience are «non-resources» and cannot be converted into other resources to bring advantage in the labour or education market; immigrants are required to learn new behaviors, probably a new language, understand new rules and to adapt to new values and another type of social space. Positive outcomes may include the recognition of migrant skills and knowledge, developing new cultural and linguistic competencies or personal change toward something better (Lodigiani and Sarli, 2017). In some way, migrants have experienced migration as a «traumatic» event in their life, but this experience paradoxically motivates and immunizes them, acting as a trigger to get ahead or to overcome difficulties.

Therefore, the use of the biographical approach could allow to analyse the success stories of young people with migrant background in education. In Migration and Biography (1990) - one of the first biographical investigation on migration -, Ursula Apitzsch shows empirically that young Italian migrants in Germany generally develop an intercultural disposition that may lead to upward mobility in the receiving country, contrasting the working-class position of their parents: this approach provides a methodological way of looking at problems and conflicts, but also of examining individual competencies available to the subjects as ways of coping with crises in migration situations through biographical resources (Apitzsch 
and Siouti, 2014). Stories of educational success of immigrant students could be studied not considering their achievement as individual exceptions to the usual pathways of group members. From a sociological perspective, the successful cases can tell us a lot about how structural conditions of inequality can be overcome and resilient students are to be regarded in relation to institutional processes and structural opportunities that allow their educational success despite the disadvantaged background.

Furthermore, biographical analysis has proven to be an excellent way of making theoretical sense of social phenomena, especially in education (Hernández and Villar, 2015) and migration studies (Apitzsch and Siouti, 2007). The biographical approach offers the possibility to integrate the perspectives of individual and society through the biographical organization of life experiences and the temporal transformation of social structures, assuming ethnic difference not merely in terms of the reproduction of predestined outcomes, but rather in a dynamic fashion, where students are part of a complex process that may no doubt reproduce inequalities, but are also largely able to reduce its effects. This approach provides an idea of the genesis of the course of social events and social changes - typical consequence of migration -, and records social reality from the perspective of acting and suffering subjects, as well as possible resources for coping and change, thanks to the ability to shape which is social self-referentially and to place oneself in relation to society (Alheit, 2005).

\section{Aims and methodological choice of Su.Per. project}

This theoretical and methodological frame represents the starting point of an on-going research project, called Su.Per. (SUccesso nei PERcorsi formativi degli studenti di origine immigrata - Success in educational pathways of students with immigrant background), promoted by CIRMiB (Centre for Initiatives and Research on Migrations) at the Università Cattolica del Sacro Cuore in Brescia. The research focuses on successful students on immigrant background, aiming at collecting and analyzing autobiographies of students attending upper secondary schools; identifying personal and social factors that lead to the educational excellence; highlighting difficulties and obstacles that these youngster have to face; reconstructing dynamics that turn disadvantage into advantage thanks to individual capacities and contextual conditions.

These successful students have been selected by specific criteria, emerging from a literature review (Santagati, 2015) and from focus groups with teachers, such as: good educational integration, high performances, high cognitive skills, good relationships with peers and teachers, high non-cognitive skills (perseverance, grit, determination, strong motivation to studying, high ambition), openness to democratic value and intercultural attitude.

The research project involves a group of 65 immigrant-origin students aged 14-19, males and females, foreign-born and native-born, with 23 different citizenships and attending different kind of upper secondary schools (lyceums, vocational and technical institutes), in the province of Brescia, a Northern emblematic area of multicultural Italian schools. These students have written independently "educational autobiographies" following a grid of auto-interview, that help them to tell relevant experiences, encounters, emotions, sentiments, choices, in their educational trajectory, remembering the past educational life, reflecting on their educational present and imagining the future, analyzing success and failure, and finally giving advice to other students to encourage their educational path. The grid is structured in 34 points (as described in the following table), with an introductory presentation and a closing section on personal data. 


\section{Table 1. Grid for the "educational autobiography»}

Self-Presentation 1.I introduce myself. Who I am, where and when I was born. Main characteristics and qualities. My family.

2. I recall the most important events of my educational pathways, as I'm watching a movie. Good and bad moments. I still remember the kindergarten .... First memory at the primary school ... The transition to lower secondary school.

3. Teachers and classmates I don't want to forget.

Past

4. Places I want to remember.

5. Memorable moments. I remember that time ...

6. The choice of upper secondary school.

7. The effect of immigration (or migration of my parents) on my past educational career.

8. Positive and negative aspects of the upper secondary school.

9. Class photo. Nice and ugly elements of my classroom.

10. Studying, what I like more.

11. Relationships with teachers.

12. The most important friends.

13. I remember a very happy moment at school. Positive experiences and words, praise I received.

14. I remember a very difficult moment at school. Negative experiences and offensive words.

15. A success that I have achieved.

Present

16. A failure that I have experienced.

(Upper Secon-

dary School)

17. I tell of when I felt fragile and disadvantaged.

18. I tell of when I suffered from an injustice and I felt discriminated.

19. I tell of when I reacted to an injustice. How did I overcome an obstacle or a failure?

20. I felt of having a chance at school when ...

21. The effect of immigration (or migration of my parents) on my current educational experience.

22. My teachers have asked me to write my story, because I am a "good student". What does it mean to be among the best students? Do I feel an «excellent student»?

23. What helps me to be a «successful student»? Personal skills and abilities. Values and models. Projects and ambitions. My family. Teachers. My friends. Experiences outside school. Important people for my career.

24. I believe and trust in school/teachers when ...

25. Expectations toward the school I'm attending.

26. Results achieved and still to be achieved in my educational path.

27. What would I like to do after finishing upper secondary school?

28. What would I like to do in my adult life?

29. Work experiences and ideas for work.

Future

30. In my future I will see: improvements and goals.

31. In my future I will see: risks.

32. Where do I imagine my future?

33. Chance for the future in Brescia.

34. Advice for other students younger than me.

Information Fantasy name, birth place, birth place of parents, year of birth, composition of the family, school attended, places where I lived, spoken languages, educational level of parents, parents' job

Source: Su.Per. Project, M. Santagati 2017.

The choice of the method of «educational autobiography» is quite traditional and, undoubtedly, not new in sociology. «The Polish Peasant in Europe and in America» is the first sociological research on the importance of people representing and reflecting on their own lives and relationships, including letterwriting, life stories, and also an «autobiography of an immigrant,» some hundreds of pages long. Life writing is central in the sociological view of social life of Thomas and Znaniecki (1918-20) because the new ways in which people represent themselves in social change, deriving from migration, highlights that 
people construct themselves in situational, relational, responsive ways, with representational forms of life writing (Stanley, 2010: 139-140).

Autobiography is an interesting technique for social research, that includes answers to three questions: what do we mean by the self? What do we mean by life? And what do we expected to succeed during writing? (Plummer, 2001). Self-writing is a narrative construction of self that people develop starting from the events of his past, but which can also concern the present and the future, in which narrator and protagonist coincide. It allows to fix aspects of your own history, manage them, modify them, reconnect them in a cognitive sense, give meaning. Differently from literature, in social science writing is not a goal in itself, but it is a vehicle of thought; differently from psychology, sociology supposes the existence of a collective referent in which to situate the single life; differently from history, time is not the starting point, but the result of a choice that places in brackets primacy of present to reflect on how and why present is going to open to the past, retraced and recognized ex post (Bichi, 1999: 28-29).

Life-writing is a form of thought, is not immediate as orality, is a description of second level that allow to take distance from lived experience, obliging to a synthesis and a reflection on educational experience. Even if writing is difficult, it can offer imaginative spaces to build resilience and resistance and to forge the self even more in a evolution process facilitated by writing, in a sort of communion with others (Merrill and West, 2009). Starting from this reflections, this study develops a different discourse on (in)equality in education in sociological perspective, because unexpected educational pathways permit to identify the social logic enrolled in the single case, contributing to the sociological knowledge of the relationship between micro-macro, action-structure, individual and social change, especially in situation of social fracture and discontinuity (Rosenthal, 2004; Cardenal, 2016). Autobiography represents a methodological choice that link individualization and socialization, individual experience and collective framework, capturing the reflective becoming of the relations between the self and the social world ${ }^{4}$.

\section{The case of Destiny}

In this last paragraph I will use the biographical approach to explore what it can mean to be required to display agency against the disadvantaged immigrant background, what are the individual and social condition that allow improvement through education. I will use the case of Destiny, a 16-years old girl with Moroccan-origin, born in Italy. Her story is emblematic of the transformation of the Italian school system, due to more and more widespread multi-ethnicity. Italy was featured by a rapid evolution of pupils of immigrant origin, which took place with exponential increase, especially since 2000. In 2016 a large and stable group of pupils without Italian citizenship is present (814,851 in 2016/17, corresponding to $9.2 \%$ of the total school population according to data of Ministry of Education). Firstly, the principal impulse to growth was the arrival of foreign minors from their countries of origin, thanks to family reunifications. Recently, the growth of immigrant-origin students in Italian schools has been due to the increase of the number of students born in Italy from immigrant parents, like Destiny. In 2016, they are 470,000 and represent almost $60 \%$ of non-Italian students. In the Italian schools, moreover, Morocco emerges as one of the most numerous citizenships (with Romania and Albania), a community of older settlement,

\footnotetext{
4 There is also a close connection between the educational autobiography written by students with an immigrant background and the grid elaborated by the researcher. It is useful to refer to the term "auto/biography" (with the bar) to draw attention to the interrelation between process through which we build our lives, thanks to autobiography, and the lives of others, through biography. We cannot write the stories of others, without reflecting on our own biography, on our social and cultural context, and also on our subjectivity and on our values. Even the choice of a topic for a biographical study tends to be rooted in our personal and professional biographies (Stanley, 1993).
} 
characterized by a significant length and stability in the presence of families, especially in the Regions of Northern Italy, a relevant presence in the school system in every educational level (Santagati, 2018).

In fact, Destiny lives with her parents, immigrated to Italy for labour reasons a long time ago and wellestablished in a Northern province in Lombardy (Brescia) with a high rate of immigrants, where their two daughters were born (24 and 16 years ago). Destiny parents have a middle-high cultural capital (her mother has a diploma and her father is graduated), but they work as unqualified workers and belong to the working-class. Although her low socio-economic integration (typical of Italy, see par.1.1), the family continues to invest in the education for their children: Destiny has a sister, graduated in aeronautical engineering, and she is attending a lyceum and she would like to continue with university studies. At the time of the research, Destiny was attending the III year of a scientific lyceum in the province of Brescia. Data collected by the Ministry of Education point out the scarce presence of immigrant-origin in lyceums and their concentration in technical and vocational schools. However, the choice of enrolling in lyceums is increasing, especially among girls and second-generation students.

Destiny starts her autobiography with a self-presentation, choosing the fancy name of «Destiny»: already in her name, as we will see in her story, she refers to a future-oriented vision of life, driven by ambitious educational and professional project, considering «destiny» both as an existing force that determines the future outside human control and as the chance for people to control and take charge of their own destinies. In her name appears the tension between (re)production of a disadvantaged social destiny - determined by gender/cultural/ethnic/religious features - and personal/familiar/social improvement, through educational choices and investment in long-term life project (Dausien, 2015). This is the framework within which agency and action can be unfolded.

«My name is Destiny. Me and my sister (who is 24 years old) were born in Italy, whereas my parents are both from Morocco. Although my parents were born in Morocco, they've spent half of their lives in Italy. During my life, I've seldom visited Morocco, but those travelling experiences were enough to make me understand that belonging to that country is a real fortune... I understood that I would never find such a background, such a lifestyle anywhere else.»

There is a sort of tension between something already written (immigrant family destiny) and something to be re-written. Destiny is looking for a new sense of learning and life experience («belonging to Morocco is a real fortune», a «unique» background), in which agency emerges from the text itself narrating life in innovative way. The biographical construction represents this tension between reproduction/ transformation, subject/structure, and acts as a reflective process, it is a social demand on the individual to accept responsibility for their acts (Evans, 2014).

"Now I'm 16 years old, I'm a student in scientific lyceum, an upper secondary school. I think I've changed a lot during my life: I'm less shy, more responsible, stronger and (I hope) wiser than I was before, especially after some experiences in my life.»

Starting her presentation, Destiny explicitly introduces a clear example of her «biographical learning» (Alheit and Dausien, 2000): some individual/familiar experiences are considered by the girl important resources for learning. Learning is not solely o mainly about acquisition of skills and knowledge, but is a more holistic process: body, mind and emotions are intrinsic to the construction and transformation of life experiences which then become integrated into the individual's biography (Morrice, 2014: 151). 
Destiny refers in her narration to the family experience of migration and to the educational pathways: she considers learning as a process of growth in terms of strength, wisdom, strength, etc.

Destiny underlines the importance of her family: generally, immigrant families are a «driver for qualifications» of their children (Modood, 1993) and this orientation transmits to the young generation a success-driven habitus, which is usually a family project, transmitted to the children from a young age. Families of successful people usually demonstrate a strong commitment to education and a belief in the importance of education: practices of family involvement seem to counterbalance disadvantaged origins and become the driving force for educational success. Migration takes on a central role in the development of a specific family ethos, oriented to sacrifice, social redemption and upward mobility (Colombo and Santagati, 2010: 27-28), which is typical of a transitional generation who, often in the face of parental failure, believe in hard work and commitment in order to succeed in their personal or family project and to find a «good place» in society.

"I'm lucky to be surrounded by a family that believes in me, supports me and cares about me and my future. My parents' greatest desire is that I will find my place in this world. My sister is my role model: she's always been a brilliant student and now she's getting her degree in aeronautical engineering. I think that an older sister is a life gift: she can make life less difficult to you with her wisdom, giving her guidance and helping you with your problems.»

Then, Destiny tells about her educational past starting from the experience of pre-primary and primary school. She places greater importance and interest on the cognitive dimension (she is very focused on learning letters, numbers, math, etc.), whereas - as we could read after - she is less concerned with schools as an arena for peer relationships. In her perspective, teachers play a vital role in her school pathway, giving approval, providing educational and emotional support, encouraging and motivated her to study harder and harder to continue reaching excellent results.

"As I started to think back about school life, I can say that little of my memories are from the nursery school, I mean, I have little or no memories of that period... I can just say that I loved preschool and I had amazing teachers... I remember when, at the end of nursery school, educators used to teach us letters and numbers through songs. Than I moved from preschool to primary school. The transition to primary school was traumatic for me; I remember when my mother used to wake me up at seven ... Those first lessons at primary school were interesting, I remember that I immediately loved math, especially after the fact that the teacher praised me in front of the whole class saying that my math test was excellent, without any mistake. Since that day I've studied hard, especially math, and, of course, other subjects.»

Transition to lower secondary school creates a discontinuity in the educational path of Destiny: she remarks the idea to stay focused on studying, especially math - the subject she prefers and probably considers more important. More difficulties, in her career, correspond always to more commitment and orientation towards engagement, as strategy to overcome problems. She tries to compensate, with this attitude, the unhappiness deriving from relational problems with classmates. They don't talk to her and show prejudice: she decides to not care about this question and look for satisfaction only in studying.

"The transition from primary school to lower secondary school was difficult for me, because, in addition to that, me and my family moved to another house; I had to get used to a new school, new teachers, new friends and a new town. Everything around seemed different to me: teachers were stricter then the ones 
I had in past, I lost my school friends... I started concentrating on school and studying even harder than I used to do, especially math, which I found more difficult than in the past. I made some new friends (some girls), but most of the students didn't even talk to me, because of a prejudice towards me. First, I felt unhappy about their behaviour, but sooner I realized that I was giving to that more meaning and importance than it deserved, so I stopped caring about that.»

Another passage is represented by the crucial choice of upper secondary school. The choice of attending a scientific lyceum is driven by the passion for scientific subjects and by the fact that her best friend chooses the same institute. The transition is not simple, but Destiny follows the strategy to face directly personal, scholastic, relational problems and go on, especially: when studying become heavier, when peer relationships are not idyllic, when her friend moves away, when she feels sad and alone, when lessons are badly organized and taught. Finally, she decides to change again school, moving to a lyceum known as the best in the area: probably with the agreement of her parents, she is always looking for the best opportunities in educational field and for a continuous improvement through education. She is afraid to fail, but she trusts into the teachers' help.

"The end of lower school was the moment when I faced a crucial choice: which upper secondary school? I chose the school which focuses deeply on math and sciences, because I've always loved these subjects and, in addition to that, because my best friend chose it too. I spent first years at secondary school in a daze: more and more homework, more difficult subjects... I faced with my problems and moved forward. I made new friends and I can say that although my relationship with other students was not idyllic, it was more harmonious than in the past (anyway sometimes there were some quarrels). During those years I spent most of the time together with my best friend, because she could understand me ... she was my confidant. I felt completely sad when, at the end of the first year at secondary school, she told me she would move to England... To me it was the end of the world... The second year at secondary school was even more difficult; without my best friend I felt completely alone, and I had lot of difficulties in studying physics. In addition to that, the course of physics was bad tanght and organized ... I felt disappointed about that situation because I loved physics and it was a central part of the school curriculum, so I feared the worst, I feared of failing.In the end I decided to apply to another school and got into. It was a "last-minute decision" so I submitted my application to a school known for being one of the best in the area. First months in the new school were particularly difficult because I had to catch up on several subjects. It was a real race against time! Thanks to teachers' help, I finally caught up to other students.»

Reflecting on the impact of migration on her past, Destiny remarks that «being foreigner, being Moroccan, being Muslim» are gifts and talents, not a problem inside and outside school: she defines her identity declaring her pride to be Moroccan, but also to be half-Italian, since the experience of living abroad has changed her. Destiny words can be read through the lens of «biographicity» (Alheit and Dausien, 2000; Alheit, 2015), a key competence in late modern societies by which individuals continually re-interpret their lives in the social contexts in which they make new experiences and link these new experiences to what they already have learnt, narrating and attributing coherence to ruptures in biographical trajectories in the context of flexibilised world (Hernàndez and Villar, 2015). In fact, the educational careers of nonItalian students enrolled in secondary schools follow a non-standard trend, as their migration experience (or of their families) affects the continuity of their school performance. When telling and writing their story, generally these students highlight that migration is the reason for the discontinuity of their careers - marked by errors, failed attempts, wrong choices -, inevitably affected by obstacles, difficulties, extraeffort, which however help them find their way and their own educational and professional career. Break, 
in some ways, forces to continuous learning through experience and valuable life lessons, with a personal commitment in producing a coherent story of self, a great reflexivity on her/himself. Destiny, as other students, is able to find (biographical and educational) resources to put in discussion her situation marked by an immigrant background, perceived as a negative label and a limit, to find the necessary strength and grit to overcome obstacles and uncertainty, and to obtain the planned goals in the educational field.

\begin{abstract}
«Being foreigner or Muslim was never a problem for me inside and outside school; I think it is a sort of life gift. I'm proud of being Moroccan, and I think that even if I will spend all my life in Italy I will never lose my roots; Morocco will always be my home. But I'm also proud of being half Italian, because living abroad has changed me. First, living abroad has encouraged my strength, because although I've faced uncertainty and obstacles, I realized that I could go forward and that has become my goal. Second, I was given the opportunity to make fantastic friend and to create an amazing school career as well as to learn some valuable life lessons. Third, I've embraced different cultures and lifestyles and all that have enriched me; I believe that being from another country, speaking several different languages, experiencing different culture and lifestyles, having different religious beliefs encouraged also my self esteem; I often think: 'I speak many different languages, I'm a good students, I love my religion, what else to desire in life? I feel happy when I can point out that most of foreign people got a degree at university and found their place in this world. They succeeded in life. They gave an important life example because although they have different roots and come from different country, they were strong and succeeded in their lives; if they could do all that, maybe I can too, maybe, working hard, all people can!»
\end{abstract}

Migration is, in Destiny autobiography, an important biographical experience and knowledge gained during the course of life of her family, and also a driver to develop other resources and non-cognitive skills (grit/persistence: ability to sustain interest and effort and to persevere to accomplish a task/goal; initiative, adaptability, social and cultural awareness, etc.: WEF, 2015), with the possibility to draw on such resource of experience (migration) by exercising agency in the shaping of her life (Tsiolis, 2012). Consequently, biographical experience of family migration do not necessarily lead to failure at school. On the contrary, migration acts as a multiplier of personal resources (languages, cultures, lifestyles, religions, beliefs, attitudes, etc.), increasing self esteem of a good student with an immigrant background that works hard: on these resources, Destiny draws upon when she acts, takes decisions, makes plans or just tell her life story, on experiences (lived or possible not-yet-lived-life). Destiny can become also a model and an important life example for the emancipation of the whole group and teaches strategies to facilitate educational success despite the disadvantaged background.

Reconstructing her present experience at school, Destiny highlights the institutional conditions and the structural opportunities that allow her educational success despite the immigrant background. Her institute is particularly involved in intercultural projects, giving equal opportunities to all the students, independently from culture, religion, language, ethnicity; fostering the love for sciences; recognizing and accepting differences; emphasizing on positive interaction between students belonging to different cultures (Santagati, 2016). According to Alheit And Dausien (2000), biographicity is never free from societal structures, even if it is primarily to be regarded as an agency. In other words, «there is no mere structural influence which determines directly the individual's reaction but social structure is both constitutive of and constructed by individuals' (re-)actions» (Ibidem: 410). School projects, educational strategies and teachers play a vital role in Destiny experience, teachers who have good relationships with her, increasing the chances to successfully manage the educational pathways, encouraging to use her background as a positive asset and offering educational and emotional support. 
"When I think about my present school experience, there are many things that come to mind. First, I noticed that in my school a special importance is given to foreign students, especially through projects that give the opportunities to experience diversity as personal and educational enrichment, sensitize people to multicultural presence and prevent racism. When talking about negative aspects in my school I can say that I haven't noticed yet anything bad. Certainly, this school has encouraged my love for subject such as sciences and math. Since the very beginning of my school experience bere, teachers have believed in me and belped me, and I hope that, one day, I will recompense them for their help in some way. I can say that my relationship with the teachers is good as well as my relationship with other students in the class.»

Despite successful performances, Destiny doesn't feel well integrated into her classroom. However, she acts in a rational way in a situation of incongruence between tools and goals: she has not adequate means to pursue her goals (have good relationships with peers as within family), she has to modify her belief on their values. In fact, she declares she is not interested in friendships or, better, she has to renounce to this dimension of her life, she is devoted only to study, without wasting time. It seems that she is satisfied only when, after hard work, she reaches good results which are new motivations to reach other objectives, overcoming limits and barriers.

"But when talking about the students, although my relationship is good, I don't feel myself completely happy or integrated in the class; I hope that our relationship will improve, because I think that developing good peer relations can establish a positive climate in the classroom: we will live our days peacefully and in a good way, we could share everything and we will be like a family. I must specify that at the present I'm not really interested in making new friends or developing friendships, I am devoting myself to study because soon there will be the exam and I'd like to pass it in a good way, so there is no time to waste. I really love the moment when, after having worked hard, I can achieve good results, that's what motivate me and help me to carry on, to go beyond limits... I think that limits exist just when we can't go beyond them.»

A crucial role for successful immigrant students is played also by friends from both the same linguistic cultural background and from natives, whose presence helps to overcome loneliness. However, Destiny explicitly writes about the fear of others and the risk of discrimination and rejection towards people that are considered different. Destiny describes her reaction and the attempt to differentiate from these «bad» people that hate different people, defining herself as better than them, a «strong girl» that gives not importance and relevance to this kind of people.

"What scares me most, is that, even if we live in 2017, there still are envious people who try to bring
you down, to create barriers, to put roadblocks in your life journey, etc. just because you're different, or,
maybe, even better than them. There are still many immature people who laugh at someone's physical
appearance. Verbal or written aggressions are still a common place in everyday life, I've heard or read
it, but, fortunately I'm strong and I don't give to them more meaning and importance than they deserve,
I don't care about them And I always try to show that although I'm different, I'm as good as anyone
else or maybe even better than the others.»

Destiny is considered by her teachers one of the best «immigrant» students in her school and she is wondering why she is selected to participate to the Su.Per. project. She shows her capacity to reflect on herself, listing a wide group of qualities, features and criteria to identify these students: good marks, competitiveness, resistance, maturity, good integration, self-esteem, self-confidence, ambition, coherence. These cognitive and non-cognitive skills are qualities socially determined, capable of producing value, 
learnt by training and development (Zhou, 2016). These non-cognitive skills are pattern of thought, feelings, behaviors, personal traits, motivations, and attitudes. Destiny, as other resilient immigrant students (OECD, 2016), shows important individual resources: she appears more motivated, more engaged and more self-confident than their disadvantaged low-achieving peers.

"When my teacher asked me to take part in this research project because she considers me one of the best students in our school, I was very happy, and I immediately accepted; frankly, it was (and it is still) bard to believe that I'm one of the best. In my opinion, being one of the best means you believe in yourself, you don't give up and you fight for your dreams. I'm still asking myself why my teachers chose me ... maybe for good marks? Maybe because I'm more mature than my age implies? Or because I can easily integrate myself? Or because I have a good self esteem, I'm competitive and I always remain myself no matter what people say or what can happen? I think that my parents (especially my sister) have always supported my learning. Also my teachers, who have always helped me since the first years at school, have played an important role in supporting my learning. All these people are the most important in my life journey.»

In this pathway, Destiny feels the support of her parents and her teachers: the meaning of migration as an investment for the future creates a strong sense of pressure and obligation of children towards parents, but emerges as part of an optimistic vision of the immigrant as someone who hopes in the improvement of life conditions and in social mobility for the whole family. The fact that immigrant parents were mobile and ambitious enough to migrate already distinguishes them from non-immigrant families. Aspirations are indeed a key explanatory factor of the paths of immigrant families and their children, as parents' high ambitions translate into support for and expectations of children's perseverance in education (Keskiner, 2016). Moreover, teachers serve as mentors and motivators, reinforcing the aspirations of second-generation students, providing advice and motivation (Rezai et al., 2015).

"The best way to win in your life is success, through success you can show that you are valuable, you can show your richness inside, just by being yourself. Of course, failure is a part of life; since we are all bumans, we are not perfect and we can fail. Sometimes I think that I can't do anything good in my life, that I'm not enough, etc. and, when thinking that, I feel as if I'm walking in the darkness. But I try to react; I listen to music (to rap music), because it helps me and thanks to music I feel much better. Sometimes it's hard, especially after aggression or after having found out that a friend has said nasty things behind your back. I'm a strong person, but when I discover that a friend has said nasty things behind my back or when I lose a friend to me it's the end of the world...In these moments I always start thinking: "what's wrong in me?" Thanks to several life experiences I've understood what to do, how to react... I've understood that when you fall, you fall on your own and you stand up again on your own; that you win and lose on your own and you go on your own. If a friend says something nasty on your back, if he mocks you and doesn't help you, don't care! It means he was not a friend.»

In a sort of appraisal of her biography, Destiny give to success the meaning of redemption, the chance to manifest her value without filter and false masks, the possibility of winning over people that create obstacles and are not true friends. She expresses an interesting strategy to achieve life success, considering failure a fundamental part of life and the first step to react and try new way to move on. Through several life experiences, Destiny become aware of the meaning of life, as a turnover of success-failure, fall-stand up, lose-win, etc. In this process, empowered by the migration/familial/school experience, she learns perseverance and grit to accomplish long-term goals. Grit is a strong predictor for educational attainment and achievement: individuals who reflected on failures, in fact, tend to have more grit and per- 
form better on a sustained attention tasks, since reflecting on failure can improve perceived perseverance and performance on cognitive tasks (Zhou, 2016).

Finally, Destiny writes about her future, hoping to have access to the best universities, to find her place in society, to continue cumulating success. She has not a clear idea about the job she wants to do, but she has a positive attitude toward life and she think that her immigrant background will be a resource, a strength point, with a high trust in education and an investment on studying that makes her indestructible and undoubtedly will improve her life conditions in the future.

"In the future, I hope that school will empower my knowledge but also myself, making me a more mature, more responsible person... I will go on my way, I will do my own best in order to achieve more and more, especially because I'd like to submit my application to the best Universities and I want to find my place in this world. After finishing this school, I'd like to submit my application to University. At the question "What kind of job you'd like to do?" I always give vague answer, because I don't have any precise idea about that. I love math, it means that, after university I can become a teacher at school or at university; it's a good idea but I'd like to do something else, maybe something more specific in the field of math. At the present, I can say that I'd also like to study pharmacology, or to be a researcher in the field of science, or, maybe, I'd like to do something in the field of robotic engineering. I've a positive attitude towards life, and I believe that being foreign won't be a problem in my future, on the contrary, maybe, it will be a resource. I think that being foreign can be an obstacle at the very beginning of one's life journey abroad (even if I must admit that I've never had "racial" problem), but with strength, hard working, being yourself, you can show that you are indestructible, and you can improve your life condition. Now I'm devoting myself to study and when I will finish, whatever will be, will be.»

Destiny autobiography finishes with some advice to peers and friends («be strong and brave»), in which Destiny summarizes her life strategies to turn disadvantage into advantage, through reflexivity, biographical work and drawing on biographical resources. Strength, grit, courage, fight, resistance are character qualities - describing how students approach their changing environment - developed through life experience and educational pathways. Destiny expresses a traditional and acquisitive idea of education as mean of social mobility, that can take advantage of rarity of difference, viewed as unique gift, an added and competitive value.

"If I'm asked to give some suggestions to other students, I will answer like that: "Be strong and brave". In this "toxic" world, you need to go beyond, you must follow your hearth, and let your intelligence to guide you and your courage to enforce you; don't care about unimportant things. Don't feel sad because you are foreign or different, because it's a life gift and if someone insults you, remember that these people do that because they are less than you are. Fight, fight, fight, show that you're better than anyone else, be unique and care about your future. Lot of people succeeded in life, thanks to their courage and hard working; if they could, perhaps I can, perhaps we can! Once again: BE BRAVE”.”

\section{Concluding remarks}

Destiny autobiography is only one case among several successful pathways of immigrant students through the Italian educational system. However, we know that it is quite representative of second-generations' trajectories, who often improve their situation, achieve the same educational levels as their Italian classmates and choose long-term and more demanding studies. In fact, second-generation students improve their skills and school performances with respect to first-generation ones, and are more and more present in the general track in secondary education and in higher education. 
The career of students with an immigrant background is linked to a learning process - like those of Destiny - which is deeply rooted on the migration process. At the same time, migration appears as a biographical break that become resource; an experience of familiar sufferance and failure, but also a source of a biographical learning; a chance of reflexivity on failure and of awareness of disadvantage; an experience that transmit and foster non-cognitive skills - learnt with the support of family/teachers -, that are strong predictor of educational success.

Furthermore, this meaning of migration that emerges in Destiny story expresses also a political tension, linked to the role of immigrant students that succeed at school can play in social change, experimenting and implementing strategies to reduce inequalities. This transformative role of students has to be supported by researchers through multiple tasks: listen to them, give directly a voice and a possibility to express themselves, recognize their freedom and creativity in their narrating life, support their learning, facilitate their biographical work, read their life writing with more dialogic and sharing lens through which avoiding colonize their social/educational experiences (Merrill and West, 2009). This perspective recalls the transformative role we play as scholars of autobiographical narratives and what social/public roles we could play, considering the power that reading and writing life stories can have in engaging critical thinking, exploring subjectivity, and promoting counter-narrative on educational inequalities (Hipchen and Chansky, 2017).

\section{Bibliographic references}

Alheit, Peter (2005): "Stories and structures". Studies in the Education of Adults, 37 (2), 201-212.

Alheit, Peter (2015): “¿Identidad o biograficidad?” in Francesc Jesús Hernández i Dobon \& Alícia Villar Aguilés (ed.): Educación y biografías. Barcelona: Editorial UOC.

Alheit, Peter \& Dausien, Bettina (2000): “Biographicity as a basic resource of lifelong learning”. In Peter Alheit (ed.): Lifelong Learning inside and outside schools. Roskilde: Roskilde University, University of Bremen and University of Leeds.

Álvarez Sotomayor, Alberto et al., (2015): “Cuando la segunda generación no se queda atrás: evidencias sobre el rendimiento académico de los hijos de inmigrantes en el caso andaluz”. Estudios sobre educación, $28,51-78$.

Álvarez Sotomayor, Alberto et al., (2018): “¿Desventaja académica de los hijos de inmigrantes? La excepción canaria en el contexto español”. Revista Española de Sociología, 27 (1), 83-106.

Apitzsch, Ursula (1990). Migration und Biographie. Bremen: Habilitationsschrift.

Apitzsch, Ursula \& Siouti, Irini (2007). Biographical analysis as an interdisciplinary research perspective in the field of migration studies. University of York.

Apitzsch, Ursula \& Siouti, Irini (2014): “Transnational Biographies”. ZQF, 1-2, 11-23.

Azzolini, Davide \& Barone, Carlo (2013): “Do they progress or do they lag behind? Educational attainment of immigrants' children in Italy: the role played by generational status, country of origin and social class". Research in Social Stratification and Mobility, 31, 82-96.

Bertozzi, Rita (2018): "University students with migrant background in Italy. Which factors affect opportunities?". Italian Journal of Sociology of Education, 10 (1), 23-42. 
Bichi, Rita (1999): “Campo biografico e intelligibilità longitudinale”. Studi di Sociologia, 1, 27-54.

Bonizzoni, Paola, et al., (2014): “Teachers' guidance, family participation and track choice: the educational disadvantage of immigrant students in Italy.” British Journal of Sociology of Education, 37 (5),702-720.

Bourdieu, Pierre (1990). The logic of practice. Cambridge: Polity Press.

Bourdieu, Pierre \& Passeron, Jean Claude (1970). La reproduction: Eléments pour une théorie du système d'enseignement. Paris: Minuit.

Cardenal, Eugenia (2016): "Biografía y relato en el análisis sociológico. La aportación de la escuela BNIM (Biographic Narrative Interpretative Method)". Revista Española de Investigaciones Sociológicas, 155, 55-72.

Cebolla Boado, Héctor (2014): "Inmigración y educación: los problemas tempranos de rendimiento escolar de los hijos de los inmigrantes" en Joaquín Arango et al., (ed.): Inmigración y educación: mitos y realidades. Barcelona: CIDOB.

Ceravolo, Flavio (2016). Cervelli in transito. Altri giovani che non dovremmo farci scappare. Roma: Carocci.

Colombo, Maddalena, \& Santagati, Mariagrazia (2010): "Interpreting social inclusion of young immigrants in Italy". Italian Journal of Sociology of Education, 1, 9-48.

Colombo, Maddalena, \& Santagati, Mariagrazia (2017): "School integration as a sociological construct: measuring multi-ethnic classrooms' integration in Italy" in Mariella Espinoza-Herold, Rina M. Contini (ed.): Living in two homes. Integration, identity and education of transnational migrants in a globalized world. Bingley: Emerald Group Publishing.

Crul, Maurice (2013): "Snakes and ladders in educational systems: access to higher education for second generation Turks in Europe". Journal of Ethnic and Migration Studies, 39 (9), 1383-1401.

Crul, Maurice, et al., (2016). "The upcoming new elite among children of immigrants: a cross-country and cross-sector comparison”. Ethnic and Racial Studies online, 1-21.

Crul, Maurice et al., (2017). "The multiplier effect: how the accumulation of cultural and social capital explains steep upward social mobility of children of low-educated immigrants". Ethnic and Racial Studies, 40 (2), 321-338.

Crul, Maurice \& Schneider, Jens (2010). "Comparative integration context theory: participation and belonging in new diverse European cities". Ethnic and Racial Studies, 33 (7), 1249-68.

Dausien, Bettina (2015): "Decisiones educativas en el contexto de las experiencias y las expectativas biográficas. Argumentos teóricos y empíricos” in Francesc Jesús Hernández i Dobon, and Alícia Villar Aguilés (ed.): Educación y biografías. Barcelona: Editorial UOC.

Evans, Rob (2014): "Out of Europe: agency and biographicity and discourses of ethnic-cultural belonging, inclusion and exclusion”. European Journal for Research on the Education and Learning of Adults, 5 (2), 195-208.

Eve, Michael (2015). Immigrant optimism? Educational decision-making processes in immigrant families in Italy. Alessandria: Università del Piemonte Orientale.

Eve, Michael (2017): “Le carriere nella crisi: le traiettorie dei giovani di origine straniera sono diverse?” in Paola Rebughini et al., (ed.): Giovani dentro la crisi. Milano: Guerini. 
Garreta Bochaca, Jordi (1994): "Expectativas educativas y sociales de las familias inmigrantes". Papers, 43, 115-122.

Garreta Bochaca, Jordi (2011): "Las experiencias escolares de la inmigración”. Papers: revista de sociología, $96(1), 205-223$.

Hernández i Dobon, Francesc Jesús, \& Villar Aguilés, Alícia (2015). Educación y biografías. Barcelona: Editorial UOC.

Hipchen, Emily \& Chansky, Ricia Anne (2017): "Looking Forward: The Futures of Auto|Biography Studies”. a/b: Auto/Biography Studies, 32 (2), 139-157.

Kao, Grace \& Tienda, Marta (1995): "Optimism and achievement: the educational performance of immigrant youth”. Social Science Quarterly, 76 (1), 1-19.

Konyali, Ali (2014): "Turning disadvantage into advantage: achievement narratives of descendants of migrants from Turkey in the corporate business sector". New Diversities, 16 (1), 107-121.

Jackson, Michelle (2012): "Bold choices. How ethnic inequalities in educational attainment are suppressed". Oxford Review of Education, 38 (2), 189-208.

Jonsson, Jan, \& Rudolphi, Frida (2011): “Weak Performance-Strong Determination: school achievement and educational choice among children of immigrants in Sweden". European Sociological Review, 27(4), 487-508.

Keskiner, Elif (2015): "Is it merit or cultural capital? The role of parents during early tracking in Amsterdam and Strasbourg among descendants of immigrants from Turkey". Comparative Migration Studies, 3,9 .

Lodigiani, Rosangela \& Sarli, Annavittoria (2017): “Migrants' competence recognition systems: controversial links between social inclusion aims and unexpected discrimination effects". European Journal for Research on the Education and Learning of Adults, 8(1), 127-144.

Masten, Ann S. et al., (2012). Realizing the potential of immigrant youth. New York: Cambridge University Press.

Merrill, Barbara \& West, Linden (2009). Using Biographical Methods in Social Research. London: Sage.

Modood, Tariq (1993): "The number of ethnic minority students in British higher education: some grounds for optimism”. Oxford Review of Education, 19 (2),167-182.

Morrice, Linda (2014): “The learning migration nexus: towards a conceptual understanding”. European Journal for Research on the Education and Learning of Adults, 5(2), 149-159.

OECD (2011). Against the odds: Disadvantaged students who succeed in school. Paris: OECD Publishing.

OECD (2016). PIS A 2015 Results. Excellence and equity in education. Paris: OECD Publishing.

Pérez Sánchez, Carmen Nieves, et al., (2014): "Inversión pedagógica y éxito escolar del alumnado de clase obrera”. Rase, 7 (2), 410-428.

Portes, Alejandro, Aparicio, Rosa, \& Haller, William (2017). Investigación longitudinal de la segunda generación (ILSEG) en España. Informe Preliminar. Madrid: Fundación Ortega y Gasset. 
Portes, Alejandro \& Hao, Lingxin (2004): "The schooling of children of immigrants: contextual effects on the educational attainment of the second generation". PNAS, 101 (33),11920-7.

Plummer, Ken (2001). The Documents of Life. London: Sage.

Rezai, Sara et al., (2015): "Passing the torch to a new generation: a qualitative study of the highly educated second generation's receiving of parental support and giving of support to the younger generation". Journal of Comparative Migration Studies, 3, 12.

Riba-Mateos, Natalia (2004): "How can we understand immigration in Southern Europe?". Journal of Ethnic and Migration Studies, 30 (6), 1405-63.

Rosenthal, Gabriele (2004): "Biographical research" in Seale, Clive et al., (Ed.): Qualitative research practice. London: Sage.

Ruokonen-Engler, Minna-Kristina, \& Siouti, Irini (2014). "Doing Biographical Reflexivity as a Methodological Tool in Transnational Research Settings”. Transnational Social Review, 3 (2), 247-261.

Santagati, Mariagrazia (2015): "Researching integration in multiethnic Italian schools. A sociological review on educational inequalities". Italian Journal of Sociology of Education, 7 (3), 294-334.

Santagati, Mariagrazia (2016): "Interculturalism, education and society: Education policies for immigrant students in Italy". Australia and New Zealand Journal of European Studies, 8 (2), 6-20.

Santagati, Mariagrazia (2018): "Education" in Cesareo V. (ed.): The Twenty-third Italian Report on Migrations 2017. Milano: Fondazione ISMU.

Schnell, Philip, \& Azzolini, Davide (2015): "The academic achievements of immigrant youths in new destination countries: evidence from Southern Europe". Migration Studies, 3 (2), 217-240.

Stanley, Liz (1993): “On auto/biography in sociology”. Sociology, 27 (1), 41-52.

Stanley, Liz (2010): “To the letter: Thomas and Znaniecki's The Polish Peasant and writing a life, sociologically". Life writing, 7 (2), 139-151.

Stevens, Peter A.J. \& Dworkin, A. Gary (2014). The Palgrave handbook of race and ethnic inequalities in education. Basingstoke: Palgrave Macmillan.

Thomas, William I. \& Znaniecki, Florian (1918-20). The Polish Peasant in Europe and America. Boston: Richard G. Badger, The Gorham Press.

Tsiolis, Giorgos (2012): "Biographical constructions and transformations: using biographical methods for studying transcultural identities”. Papers, 97 (1), 113-127.

WEF (2015). New vision for education. Unlocking the potential of technology. Geneva: World Economic Forum.

Zhou, Kai (2016). Non-cognitive skills: definitions, measurement and malleability. Paris: Unesco.

\section{Biographical note}

Mariagrazia Santagati is Assistant Professor of Sociology of Cultural Processes at the Faculty of Education at the Catholic University, Milan. She is Lecturer in Sociology of Education and Sociology of Educational Policies, at the Catholic University, Faculty of Education, Brescia. She is member of CIRMiB 
(Centre of Initiatives and research on Migration in Brescia) and secretary of the Steering Committee. Her field of interest is the relevant topics in Sociology of education and the relationship between education and migration and processes of intercultural communication and intercultural mediation. 